\title{
Sexualidade e hermenêutica existencial em história de vida de um educador sexual*
}

Gilka Borges Correia**

\section{RESUMO}

Apresenta síntese do relato de uma das seis histórias de vida que compõem a amostra, resultante de entrevistas realizadas com educadores sexuais, em 1998, na cidade de Curitiba, PR, Brasil. Segue o fio condutor da sua formação profissional na última década. Busca uma intersecção entre medicina, sexualidade e educação evidenciando a deficiência da formação acadêmica. Sustenta o pressuposto da escola inglesa de psicanálise de que a escolha da profissão é uma resposta inconsciente do "Ego" a um chamado interno. Na linha metodológica da fenomenologia hermenêutica estabelece categorias para interpretar a dinâmica do discurso do "eu pessoal" e do "eu profissional" na sua relação com os "outros". Analisa a enunciação do discurso e articula as fases da história de vida com a construção da carreira profissional na perspectiva clássica de SUPER (1957). Desvela as fases do percurso de formação e as características de personalidade que possibilita-

* Excertos da Dissertação de Mestrado - UFPR.

** Psicóloga clínica do HC da UFPR, especialista em Sexualidade Humana e Mestre em Educação.

Recebido em 18.10.99

Aprovado em 22.10.99 
ram atitudes de enfrentamento. $\mathrm{O}$ educador sexual considera mais importante a qualidade da relação de ajuda do que a atuação técnica. A história de vida revela que sofreu influências da ideologia repressiva da sua família e do contexto social e político do Brasil dos anos setenta.

\section{INTRODUÇÃO}

Com a crescente complexidade social um processo de sexualização atingiu toda a nossa sociedade. Entre os profissionais da saúde e da educação veio crescendo uma preocupação com a sexualidade na mesma proporção que as mudanças sociais resultaram numa liberação dos costumes. Os profissionais que desenvolviam atividades de educação sexual até a década de oitenta tinham como única alternativa de formação o autodidatismo. Tornaram-se educadores sexuais ao seu modo.

A questão maior, sem dúvida, foi (e ainda é) a falta de cursos de formação que qualifiquem o educador sexual no trinômio informação-formação-prevenção, e que o habilitem a desenvolver uma metodologia adequada para as condições socioculturais da comunidade onde vai atuar.

Na minha prática profissional venho assistindo na educação sexual, na sua grande maioria pela não resolução de conflitos dos próprios profissionais envolvidos, inadequações, transmissão de preconceitos e tabus, silêncios, omissões e recalques ou o retorno do recalcado.

A educação participa no ensino-aprendizagem do papel sócio-sexual determinado pela cultura. Pretende dar conta da primeira dimensão da identidade, auxiliando a criança a responder as questões:

O que é ser menino? O que é ser menina?

Como me relaciono com o diferente? Qual é o meu lugar no mundo?

Se concebo a vida como processo de crescimento, se a sexualidade é parte integrante da vida e se os papéis sócio-sexuais são aprendidos, então educação e sexualidade estão imbricados na mesma dimensão do crescer, do desenvolver e do aprender.

Por outro lado, a Sexologia na atualidade constitui-se um amplo campo de saber e por conseguinte a formação acadêmica é indispensável. Não é possível improvisar um educador sexual eficiente e eficaz. A universidade vem mantendo-se alheia, ancorada em paradigmas de educação que privilegiam o intelectual, o abstrato, a teoria e a cognição. Os professores ingenuamente formados pela universidade são encaminhados para lidar com educandos provenientes de um contexto sócio-econômico caótico e comparecem munidos de informações e metodologias distanciadas da realidade. Não se sentem seguros para atuar nem na prevenção, nem na orientação e nem na assistência.

A omissão da universidade como agente formador promoveu uma enorme lacuna na educação sexual que dificilmente será revertida em curto 
espaço de tempo. O que me preocupa é que a omissão da universidade tem levado algumas entidades e instituições a pensarem que a formação é irrelevante e assumem atividades de educação sexual sem nenhum profissionalismo, ocupando uma posição, um espaço e um papel inadequados. Isto favorece a idéia de que qualquer um pode exercer a função de educador, mesmo de improviso, e que a formação é desnecessária. Sem maior comprometimento basta repassar a sua vivência...

É fundamental que a Educação assuma a qualificação de profissionais com uma visão pluralista e globalizante do homem e do mundo e não forme profissionais reducionistas e fragmentados, ingênuos e equivocados com a realidade social.

Muitos educadores sexuais que estão atuando buscaram a sua formação, privilegiando um "formar-se" em que pudessem abrir horizontes para a consciência das tênues fronteiras entre o orgânico, o psicológico e o social, permeadas pela cultura.

Têm tido a coragem de colocar "um pé lá e outro cá" e através de uma formação continuada, tentaram tecer um fio invisível que costurasse essas fronteiras.

Busquei desvelar as histórias de vida de seis educadores sexuais, o curso, o discurso, o percurso, a trajetória e as alternativas de formação profissional utilizadas nas últimas quatro décadas no Brasil. Apresento aqui excertos do discurso de um dos educadores sexuais sujeitos da investigação.

Desejo contribuir para modificar o paradigma da formação de professores e auxiliar na definição de critérios e concepções que subsidiem cursos acadêmicos de formação de profissionais em educação sexual, uma necessidade premente no atual contexto social do Brasil.

\section{SEXUALIDADE E MODERNIDADE}

A sexualidade esteve presente em toda a história da civilização, na ciência, na cultura, na arte e na educação. Na sociedade ocidental, os valores que determinaram as normas e regras foram construídos ao longo do processo cultural, profundamente influenciados pela moralidade judaicocristã. Até o nosso século a mulher foi valorizada à semelhança da VirgemMãe, representante do amor divino, enquanto o amor terreno e carnal estava ligado à prostituta. A vida erótica de muitos homens dissociou a imago da mulher em duas direções nas quais, afeto e prazer se excluem. Na evolução da libido a sexualidade sofre uma interdição, afasta-se da realidade e é acolhida pela fantasia. Nessa dissociação, se amam uma mulher não a desejam, e se a desejam não podem amá-la. Desprezam as mulheres desejadas, reservando para as não desejadas, respeito e valorização. No contra-papel, as mulheres submetidas à uma educação repressiva, desenvolveram uma 
atitude de pudor e castidade, própria da condição de sérias. Não era favorável a elas, que o homem as desejasse fisicamente, pois havia a crença de que a supervalorização do enamoramento era substituída pelo desprezo depois da posse. Por isso, guardavam-se puras. O casamento, a família e a maternidade era o destino natural da mulher e sua única expectativa. Assim sendo, não conseguir casar e ter filhos, era, e mesmo na atualidade para muitos ainda é, a definição do fracasso de uma mulher. Este e vários outros estereótipos sócio-sexuais ainda estão presentes no imaginário social dos nossos dias.

O "ser sexuado" no mundo contemporâneo vem sofrendo uma série de mudanças no desempenho de papéis e nos limites das práticas tradicionalmente aceitas pela sociedade, para as quais os profissionais da saúde e da educação não estão preparados para intervir. MONEY (1994) na Conferência de Abertura do XI Congresso Mundial de Sexologia registrou o descaso da medicina pediátrica e da educação em relação à sexualidade infantil, enfatizando as conseqüências da omissão no tratamento de abusos sexuais e vitimação infanto-juvenil na personalidade em formação. Salientou a necessidade de ações eficazes de informação e educação sócio-afetiva ligadas à prevenção, em função dos apelos eróticos e das facilidades concedidas no mundo contemporâneo.

No núcleo familiar a criança se dá conta da sua dimensão sexuada. Recebe dos pais uma visão de mundo e introjeta um sistema de valores que irá ser confrontado pela primeira vez no processo de socialização com seus pares. Quando chega na escola, portanto, já traz uma série de informações, valores e preconceitos aprendidos na família. A educação sexual iniciou-se a partir de todas as mensagens que a família transmitiu por ação ou omissão. FREUD (1907) em "A educação sexual da criança" já questionava: O que se pretende ao ocultar das crianças os fatos da vida sexual? Mantê-la afastada o mais possível da sexualidade pensando controlar seu comportamento? Privála de dominar intelectualmente o que já vivencia com seus pares?

A mais grave conseqüência na educação é que a dissimulação abala, pela primeira vez, a confiança nos pais e nos educadores, representantes das figuras de autoridade. Como muito bem afirmou SILVA (1979), "reprimir a curiosidade natural da criança a respeito da sexualidade é impedir uma forma espontânea de investigação, um direito de toda criança. Porém, numa sociedade organizada, a orientação e o uso desse direito acarreta deveres. Entretanto, parece-nos mais condizente com os conhecimentos disponíveis, que se ensine uma ética sexual ao invés de esconder a sua prática."

O silêncio da família e da escola passam a mensagem do mistério, do escondido e do proibido. As crianças captam essas mensagens e as incorporam no seu comportamento. Há uma demanda da criança para discutir essas questões no espaço da escola, e esta o que faz? Finge que não vê, adverte ou persegue os culpados com punições, raspa escritos, desenhos, pinta paredes, enverniza carteiras e recomeça tudo de novo sob o selo do silêncio e da culpa. 
Com a crise da família moderna, onde muitas vezes, a mulher sozinha é a responsável pelo sustento dos filhos, a realidade e a experiência indicam que a educação sexual ultrapassou os limites do círculo familiar e passou a ser, cada vez mais, uma atribuição da escola. A família a considera importante e necessária mas não tem tempo e se define como despreparada. A escola, como sub-rogada dessa sociedade, recebe por delegação a tarefa de educar sexualmente as crianças. No espaço cotidiano da escola surgem oportunidades para que se construam laços compreensivos nas situações existenciais. Reconheço como educação essa ação de levar de uma situação de existência para outra.

$\mathrm{Na}$ atualidade, entretanto, o fenômeno da massificação torna as pessoas "seres anônimos" e a mídia ocupa o papel da educação e da família. Os modismos em comportamentos e práticas sexuais são apresentados de forma banalizada e o erotismo passou a ser critério de modernidade. $O$ desempenho sexual é "ensinado" de forma vulgar, omitindo que a expressão da sexualidade é singular e livre. Quando os adolescentes dizem "todos fazem" referem-se a ninguém em particular, mas a um modelo imposto pela mídia, que não tem trazido como retorno experiências construtivas. Recebem um volume de informação diversificada de forma tão rápida que não conseguem organizar. Buscam a vivência da imediatez e o máximo de prazer. Tudo isto determina um intenso e conflitivo narcisismo, uma intolerância às frustrações e uma descrença nos relacionamentos. Diante desse quadro, que referências são oferecidas à criança e ao adolescente para interpretar o mundo que a mídia projeta dentro da sua casa? A compreensão dos costumes, as atitudes e decisões dos adolescentes vão depender da representação subjetiva que cada um consiga elaborar.

Se no mundo atual o "ser-sexuado" se fez mais claro e transparente isto não o tornou mais feliz. Falta uma atitude afetiva de acolhimento, solicitude, enlaçamento e confiança nas "possibilidades" de cada um na relação com os outros. Só assim conquista-se a liberdade para responsabilizar-se pela sua existência.

SILVA (1990), em sua aulas, costumava afirmar: “a explosão do sexo na adolescência é como uma represa que se rompe e inunda tudo. Tão mais perigosa quanto mais tempo contida. Tão mais difícil de conter quanto maior o apelo sexual e as facilidades concedidas." Os resultados desses apelos e facilidades estão presentes no início cada vez mais precoce da vida sexual entre os jovens e no alarmante índice de gravidezes indesejadas na adolescência.

\section{UNIVERSIDADE E ESCOLA: DUAS REALIDADES DISTANTES}

A universidade e a escola como campo de aplicação vêm percorrendo caminhos paralelos e participam de mundos distintos e distantes. A profis- 
são docente foi substituída pela transmissão de uma reduzida e simplista carga básica de conhecimentos (sempre insuficiente) na área específica de sua formação. Em contraponto, face a complexidade social a demanda dos alunos é cada vez maior e não encontra um profissional informado e formado, com uma visão pluridimensional, reflexivo, crítico e bem posicionado frente às complexidades emergentes de um contexto social desigual e injusto. Sucumbiu o professor a todos esses apelos. A falta de uma política educacional no país se faz sentir pelas modificações que, de decreto em decreto, de parecer em parecer, modificam e regridem a velhas fórmulas, criam novas, isto é, perdem-se num descaminho que assusta e entristece. Colocome entre aqueles que acreditam na educação como uma das possibilidades de construção de uma sociedade mais informada e de cidadãos mais conscientes da sua participação.

A partir da década de oitenta, em decorrência de maior promiscuidade, as doenças sexualmente transmissíveis atingiram as populações infantil e adolescente, chegando também na escola. A pandemia da AIDS foi o gatilho para uma chamada a um posicionamento da escola. Algumas experiências de educação sexual realizadas apontaram as deficiências pessoais dos educadores em lidar com o tema. Estudar as causas não significa estudar o fenômeno. Fiz-me questões mais do que o desvelei. Busquei conhecer as histórias de vida de profissionais que atuam em educação sexual para conhecer a trajetória e o processo de construção do conhecimento. A interpretação dessas histórias de vida e a construção fenomenológica do papel profissional poderão vir a subsidiar reflexões para repensar o processo de formação.

\section{PERSPECTIVAS METODOLÓGICAS}

A abordagem teórico-metodológico é a fenomenologia hermenêutica, uma vertente da hermenêutica cultural e existencial embasada nos ensinamentos de Heidegger, Husserl e Merleau-Ponty. Na ciência dos fenômenos devemos "ir à coisa mesmo", descrevendo o que se vê de imediato. O investigador libera o seu olhar para acolher o que lhe é apresentado. Todo conhecimento que posso ter do mundo, até o próprio conhecimento científico é construído a partir do meu próprio ponto de vista, ou a partir de alguma experiência de mundo sem o que os símbolos da ciência natural seriam sem significados.

$\mathrm{O}$ alvo da interpretação é o sentido e a atribuição de significado no tempo vivido do "formar-se educador sexual" no Brasil.

No universo de profissionais de formação acadêmica diversificada que atuam como educadores sexuais em Curitiba, PR, a amostra contou inicialmente com vinte sujeitos entre os quais seis profissionais aceitaram o convite e concordaram em participar da investigação relatando suas his- 
tórias de vida. Os discursos dos educadores sexuais abrangem o período das últimas quatro décadas. Através da des-ocultação das suas histórias de vida pretendi perceber o paradigma que os sustenta.

A questão motivadora foi: "Me fale da sua vida... como você chegou a fazer o que faz hoje?"

Os momentos centrais neste estudo são:

a) história de vida dos sujeitos;

b) definição das categorias de interpretação;

c) hermenêutica das versões;

d) articulação entre as versões.

Para compreender a escolha da profissão enfoquei o pressuposto da escola inglesa de psicanálise que afirma que a vocação e a escolha da profissão é um chamado interno e constitui uma resposta inconsciente do Ego frente a um objeto interno danificado que exige e necessita ser reparado. Decidi pela metodologia dialógica porque desejei trilhar caminhos pouco percorridos na investigação científica.

A análise da carreira profissional está baseada na perspectiva clássica da psicologia de carreira de SUPER (1975). Sobre o método de histórias de vida de professores busquei aprofundamento teórico nos textos de NÓVOA (1988, p. 18-27) que registra a crise do paradigma cartesiano. Afirma que a profissão docente precisa "se dizer e se contar", como uma maneira de compreender em toda a sua complexidade humana e científica, numa ruptura epistemológica que se refere à necessidade do conhecimento científico se constituir em senso comum: A abordagem autobiográfica faz ressurgir o sujeito face às estruturas e sistemas, a qualidade face à quantidade, a vivência face ao instituído. Enfoco o tempo vivido pelo sujeito e as condições objetivas da realidade social. Enfatizo o afetivo, pelo viés das experiências de vida, que normalmente escapam das estatísticas de uma pesquisa quantitativa.

As histórias de vida e seus percursos de formação e transformação foram compreendidas e interpretadas, com base na noção de que compreensão não é explicação. A explicação diz respeito a fatos e causas, ao passo que compreensão refere-se a vivências e sentidos.

\section{CURSO E DISCURSO DE EDUCADORES SEXUAIS}

No plano epistemológico a análise da enunciação é um modelo representacional que começa onde os modos tradicionais de investigação acabam. Aplica-se aos discursos em seus conteúdos e continentes na interpretação e na desocultação do latente, do não aparente e do não-dito de qualquer mensagem. A tônica é colocada sobre orientações de valor, 
afetivas ou cognitivas dos significantes ou dos enunciados de uma comunicação.

A primeira atividade é a leitura "flutuante", onde o investigador deixa-se invadir por impressões e orientações em analogia com a atitude do psicanalista.

Abordando um discurso dinâmico o trabalho de elaboração é, ao mesmo tempo, emergência do inconsciente e construção do discurso. É a convergência de influências teóricas e metodológicas de várias origens. Vêm diretamente de Freud o interesse pelo jogo de palavras, pelas associações, pelos lapsos, pelos silêncios. Lacan participa na concepção de um discurso em que a manifestação formal esconde e estrutura a emergência de conflitos latentes. Considera a produção da palavra como "processo" onde é elaborado um sentido e são operadas transformações.

Um triângulo estrutura a produção: o locutor, o objeto do discurso e o entrevistador. O locutor exprime toda sua ambivalência, os seus conflitos de base, a incoerência do seu inconsciente. Mas na presença de um terceiro a sua fala deve respeitar a exigência da lógica socializada. Daí surge o discurso, na passagem pelo "fluxo da linguagem" e pelo "outro".

Utilizei dois níveis de aproximação: a análise lógica e a análise dos elementos formais atípicos, como omissões, ilogismos, silêncios e rupturas, como risos ou a passagem para explicação, como "isto é" ou "quer dizer". Os discursos desta investigação foram numerados de um a seis segundo critério cronológico de realização. Cada sujeito teve em média oito horas de entrevistas.

Foram criadas seis categorias para a análise do conteúdo: Infância e memória; Identidade e identificações; Expressão da sexualidade; Adolescência, estudo e profissão; Carreira profissional e Fases da carreira profissional. A parte comum existente nos discursos foi classificada na sua categoria específica. Para facilitar a compreensão dos discursos foi apresentado um perfil sucinto dos educadores sexuais, não identificatório.

O objeto deste trabalho é o discurso do sujeito $n^{\circ} 2$ da amostra e excertos da interpretação nas diversas categorias de análise.

Perfil sucinto do sujeito:

Sexo feminino, 32 anos, médica, casada, dois filhos, família de origem italiana, nascida e criada no interior do Rio Grande do Sul. Atuou somente como Pediatra no início da carreira. Realizou um estágio de um ano no ambulatório de um Serviço de Adolescência em Hospital de Paris e está concluindo Pós graduação com Especialização em Adolescência. Dez anos de carreira profissional. Cinco anos de trabalho com adolescentes e sexualidade.

\subsection{Infância e memória}

A consciência do "eu" inicia-se com a percepção do seu ser separado do "outro" nas relações parentais e segue-se com a descoberta da di- 
ferença sexual anatômica e a aprendizagem do comportamento do seu sexo de gênero.

Eu me lembro das primeiras conversas... a minha mãe vem de uma família italiana, muito religiosa, pai muito severo, oito filhos, ela é a mais velha... e assim... de muito trabalho, muita honestidade, mas principalmente muita religião... e muito pecado... E a família do meu pai, também uma família humilde de italianos... mas a religião não era um ponto tão forte... Mas minha mãe sempre foi muito religiosa... Ela casou com 26 anos, meu pai foi o primeiro namorado. Antes ela foi para um internato para ser freira. O meu pai foi o único que estudou dos oito irmãos... com nove ou dez anos saiu de casa e foi para o seminário para ser padre... mas depois ele percebeu que não queria ser... não era aquilo... Ele chegou a essa conclusão... foi para o seminário para poder estudar... ele não tinha dinheiro... mas não queria ser padre e a minha mãe também não tinha nada a ver em ser freira... Ele continuou os estudos, fez Faculdade de Letras e depois Direito. Meu pai era professor de latim, português, não sei exatamente do quê... Eles se conheceram na igreja... Ele era cantor do coral, tinha uma voz muito bonita... minha mãe super religiosa... Eles casaram dois anos depois... e tiveram quatro filhas... Meu pai passou no concurso de Juiz e mudamos de cidade... ( $\left.2^{\circ}\right)$

A memória infantil registra todos os momentos significativos da sua vivência. A convivência com os amiguinhos aguça o espírito de investigação das crianças e elas geralmente comunicam suas descobertas e compartilham informações. Na maioria das vezes não sentem um clima aberto ao diálogo. Esta atitude favoreceria a formação de conceitos claros, evitaria o compartilhar de informações incorretas e seria uma oportunidade de desenvolver um vínculo de confiança mútua.

Com nove anos eu descobri sobre o relacionamento sexual... algumas colegas comentaram... e eu fui perguntar para minha mãe. Porque até nove anos eu achava que isso era uma coisa assim... como piada... de televisão... tipo de brincadeira... (risos) e achava que era uma coisa assim... muito errada... muito pecaminosa... uma coisa, sei lá... uma coisa que não é normal... achava aquilo uma bestialidade... eu não achava que era normal uma coisa dessas... Perguntei assim: Mãe... é verdade que precisa fazer isso? Eu fiz a pergunta esperando e pensando que ela ia dizer... - Claro que não, minha filha... ( $\left.2^{\circ}\right)$ 


\subsection{Identidade e identificações}

Em seu debate com o mundo a criança busca a verdade de si mesma e sua grande tarefa é construir sua identidade. Mesmo antes de constituir-se "ser-de-fala" já está inserida no simbólico. Na relação com o "outro" deverá construir uma estrutura, um "eu”, a sua única morada na vida.

Eu vivi num universo bem feminino... Ser menina, ser mulher para mim era uma coisa boa, me sentia um ser superior... (risos) Ela pode se dar ao luxo de ser inteligente... (risos) de ser esforçada... (risos) Tinha muito a questão de ser mãe. Eu sempre quis ser mãe... Eu dizia, quero estudar, estudar, estudar... (risos) e lá pelos vinte e dois anos eu vou me casar e vou ter filhos... Na minha vida sempre eu queria me casar... e queria ter filhos... sempre... sempre... sempre... A maternidade ficou como um valor importante... bem importante. $\left(2^{\circ}\right)$

A identidade de uma pessoa está ligada com a sua história de vida. No bojo do processo está a identidade sexual, isto é, a consciência íntima de ser menino ou menina. A criança expressa em atitudes e sentimentos a respeito de si mesmo a sua identidade de gênero.

A percepção da expectativa dos pais em relação ao papel de gênero está clara nesse discurso. A criança consegue discriminar o que se passa à sua volta, fazer restrições e inclusive julgar as atitudes dos seus pais. A criança em sua fantasia projeta sua vida de acordo com as expectativas que percebe no seu meio familiar, bem como os desafios para afirmar os seus desejos. O sentimento de ser amada e as proibições e limites marcam toda a experiência infantil. Pôr-se em questão e buscar uma resignificação para essas experiências faz parte do processo de amadurecimento. As identificações ficam evidentes em vários trechos do discurso definindo preferências e direcionamentos, inclusive profissionais. A identificação com a figura paterna foi uma constante.

\subsection{Expressão da sexualidade}

A sexualidade aceita ou acolhida, bloqueada ou reprimida, impõe-se de diversas formas e em vários contextos, em todo o discurso. Através da tentativa de compreensão, da investigação natural da criança ou mesmo da transgressão.

Lá em casa era tratado assunto de sexo... minha mãe sempre leu muito sobre sexo... ela sempre se informou muito... até porque meus pais tinham uma dificuldade sexual... hoje eu 
posso dizer isso, eles foram muito reprimidos, então como eles tinham essa dificuldade ela se preocupava muito em mostrar que o sexo era bom, que o amor era bom... porque eu sinto que eles têm uma dificuldade imensa... o casamento deles, na verdade, é um casamento que... fracassou... eles estão juntos... mas é um casamento fracassado... e muito ligado à sexualidade. Eu não percebia que eles não eram felizes sexualmente, eu não percebia isso... cência...

Só fui perceber bem mais tarde... quando cheguei na adoles-

Minha mãe explicou... contou... Ela colocou que Deus criou isso... o sexo... que era uma coisa muito boa... colocou assim nesse sentido... que não era assim... uma obrigação, não... Ela colocou que era para sentir prazer... Acho que ela colocou isso, não porque ela sentia... mas era o que ela gostaria que fosse... hoje eu estou analisando... Ela tentou me passar essa mensagem, mas depois a gente foi percebendo. Hoje, principalmente, percebo que a minha mãe, na verdade, foi muito infeliz nesse campo... Nunca falou abertamente, justamente porque ela estava ensinando para a gente... agora claro, percebo completamente diferente... Na época ela queria mostrar que a gente poderia ser diferente dela, mas... só fui compreender depois que entrei na adolescência... mas na época de criança a gente não percebia... $\left(2^{\circ}\right)$

As brincadeiras de conotação sexual hetero e homossexuais fazem parte de um desenvolvimento normal e são buscadas dentro da pureza e da integridade da criança. Embora já consciente do silêncio e da culpa são associadas ao feio, ao sujo, ao pecado. Mas o que é mais importante pontuar é a força da pulsão que apesar das proibições impõe o seu curso mesmo através da transgressão.

Na minha família predominam as mulheres. Quatro mulheres e o pai. Só tinha menina em casa... Os meus avós, os meus primos, todos moravam em outra cidade eu só tinha contato com eles nas férias... eu me lembro que com cinco anos a gente tinha amiguinha, tinha coleguinha, que a gente gostava de brincar... Aí tinha menino... tinha irmão. Com a idade de seis, sete anos, a gente fazia uma brincadeira de fazer a minha amiguinha beijar o irmãozinho de outra... na boca... Mas aquilo para nós era uma coisa proibida... tudo muito escondido... Não era o aprovado... Nossa... Era bem escondido..., no fundo do quintal... e depois tinha essa uma passadinha na boca no final... para limpar a boca... eu limpava a boca... (risos) Eu participava das brin- 
cadeiras... e de noite eu sonhava... mas eram pesadelos... uns pesadelos diferentes... (risos).....

O maior pesadelo que eu podia ter é que tinha um menino atrás de mim e que dizia: eu vou te beijar na boca. Era assim um pesadelo... e eu fugia, fugia, fugia, fugia, e ele atrás de mim, atrás de mim... atrás de mim... O maior pesadelo possível era esse... eu tinha culpa... devia ser culpa... Ao mesmo tempo que eu tinha um sentimento de culpa tinha curiosidade... aí que começava uma ambivalência. A primeira coisa que eu me lembro em relação ao outro sexo é isso aí, a culpa pelo estereótipo do externo, do beijo, tal... Mas era uma brincadeira tão diferente... $\left(2^{\circ}\right)$

A sexualidade tem que estar adequada com o papel sócio-sexual de gênero aceito pela sociedade. Não é fácil para a criança a partir da puberdade e no início da adolescência decidir "como" reagir e se comportar tendo uma solicitação externa e um impulso interno e situações novas para administrar. As primeiras experiências de relacionamentos entre os sexos podem definir padrões aceitáveis ou imprimir marcas que se prolongam na vida adulta.

No começo da adolescência, quando a gente começa a ficar cheia de curvas e atraente para o sexo oposto, começa a chamar muito a atenção... Eu sentia um ódio quando chegava um menino perto de mim e já começava a pôr a mãozinha, a tirar uma 'casquinha'... eu chamava o menino e dizia: E essa mãozinha boba... (risos) Coitado dos meninos... eles queriam namorar comigo... eu até gostava... mas ainda não queria... não queira mesmo... eu achava que tinha que estudar, passar no vestibular de medicina... eu tinha outras coisas para pensar... não que eu não quisesse isso em minha vida... $\left(2^{\circ}\right)$

As famílias divergem no trato com o corpo e a nudez da mesma forma que com o sigilo sobre o sexo entre os pais. As crianças descobrem e calamse com uma série de dúvidas. Movidas pelo espírito saudável de investigação continuam as suas pesquisas, em silêncio, e o selo do proibido já está colocado sobre os fatos da vida sexual.

Na minha casa existia a nudez... era normal o corpo humano... eu tomava banho com o meu pai, com minha mãe... e... era natural... quer dizer... até a puberdade... Não sei porquê eu comecei a ficar com vergonha... eu não me lembro bem a idade, acho que eu tinha dez, onze anos... Eu comecei a ficar envergonhada... Sempre foi normal... eu entrava no banheiro, às vezes meu pai estava fazendo xixi... ele continuava... era normal... 
até que... eu me lembro que eu não levantava a cabeça... (risos) Eu acho que foi a primeira vez que eu olhei bem... prestei a atenção... e vi que ele tinha um pênis... Meus Deus... ele tem um pênis... Ah!... fiquei com uma vergonha... porque eu não olhava... quer dizer... antes eu olhava... mas olhava como se olha orelha, nariz... Eu não olhava o pênis... Eu me dei conta que ele tinha um pênis... Veio o desejo de olhar mas não achando muito legal olhar... Mas agora é que eu quero olhar... mas eu não olhava... quando quis olhar... entrou o pudor e comecei a ficar com vergonha... Nunca mais vou mais tomar banho perto dele... decidi... (risos) $\left(2^{\circ}\right)$

A escola, como extensão da família, também oferece oportunidades de identificação e reforço do papel sócio-sexual de gênero. A sexualidade manifesta-se livremente, na maioria das vezes, na via da repressão, no vocabulário e nas pichações de muros e carteiras e na competição entre os sexos.

Na minha idéia, desde os doze anos sempre quis medicina. Porque não tinha ninguém na minha família que era médico, eu não sabia qual era a rotina de um médico, não sabia a faixa salarial de um médico, não sabia exatamente o trabalho do dia a dia de um médico. $\left(2^{\circ}\right)$

Eu sempre fui a primeira da classe... era uma coisa de desafio. Eu competia com os meninos... Eu sempre fui a primeira... eu queria uma coisa mais difícil, uma coisa que não seja tão fácil... uma coisa mais difícil...para provar alguma coisa. Eu posso... É difícil? Então eu quero... E a medicina é uma profissão difícil... é concorrido... a gente pode ajudar os outros... mas é difícil... ( $\left.2^{\circ}\right)$

Não temos controle sobre as figuras de identificação que surgem no decorrer do processo de construção de uma identidade. Muitas dessas vivências põem em questão uma série de conceitos aprendidos. Pontuo a clareza desse discurso.

A imagem do homem era o pai... E eu sempre tive uma idéia de criança e adolescente de que o homem... era aquele estereótipo do papel do macho... com uma mensagem do tipo assim... homem só quer se aproveitar... homem tem que ter cuidado... os homens só querem sexo... aquele recado de pai e mãe que dão para a gente, tipo "se cuide"... E com essa mensagem como é que a menina vai conhecer os meninos, confiar neles?... Fica muito complicado. Então para mim... o homem era meio 
animalesco... a mulher era superior... porque a mulher não é só isso... para ela o sexo é diferente... homem só quer aquilo... Era a idéia que passavam para a gente dentro da ideologia da época... com o objetivo de proteger... proteger para casar virgem... a mensagem era essa. Mas ao mesmo tempo que minha mãe passava essa mensagem ela procurava sempre conversar muito. A gente conversava... $\left(2^{\circ}\right)$

Sabemos que com base nas interações construtivas dentro da família surgem os modelos identificatórios que clarificam uma visão de mundo e favorecem a construção da identidade. Nem sempre porém, os modelos identificatórios favorecem essa construção. Nesse caso torna-se mais doloroso o percurso em busca de uma definição de personalidade.

Eu sempre dizia que ia me casar com vinte e dois anos... e ter filhos... então para quê eu vou namorar agora se eu vou ter tempo mais para frente, para quê eu vou perder tempo com isso agora? Para mim era perda de tempo... vou namorar com esse indivíduo, vou beijar, vou trocar saliva com ele... eu não estava apaixonada. Na verdade... às vezes eu até achava um menino bonitinho... eu tinha doze anos... vou casar com ele? Não vou casar com ele... E para mim sexo era igual a casamento... Mas eu podia ficar só no beijo... no abraço se eu quisesse também... mas eu não queria... não queria... Minha mãe orientou sobre proximidade e contato físico como beijo e abraço... comentou... pode beijar... pode abraçar... pode dar a mão... não deixe mexer no seio... não deixe mexer no seio... porque aí... ela sempre dizia assim: o que você deixar hoje... amanhã é mais um pouquinho... então vai devagar... ( $\left.2^{\circ}\right)$

\subsection{Adolescência, estudo e profissão}

A adolescência é uma fase de muitas resoluções. Além das modificações de ordem biológica, a dimensão psicossocial é atingida por inteiro, numa reedição da personalidade. Entre as tarefas fundamentais está assumir o papel sócio-sexual de gênero e escolher uma área de estudo para formação profissional. Estudo e trabalho são condições para ingresso no mundo adulto. Essas decisões são muito influenciadas pelo contexto cultural, pelos padrões e expectativas familiares e pelas alternativas que se apresentam como viáveis. Decisões de ordem sexual e emocional, padrões de comportamento sobre papéis de gênero, planos de estudo e carreira profissional se misturam numa perspectiva de vida futura. Nesse recorte de discurso está presente toda a problemática da adolescência. 
Eu me lembro que na adolescência mesmo eu sempre competia com os meninos... eu competia... (risos) eu queria mostrar que a mulher não era inferior... eu queria mostrar isso em qualquer coisa... no esporte... em qualquer coisa a mulher pode tanto... e geralmente até pode mais... em tudo... (risos)...Eu me lembro que eu tinha uma raiva daquelas meninas que eram assim... ai... eu tenho medo disso... ai... ai... aquele papel bem estereotipado da menina assim bobinha... ai, ai... eu vou desmaiar por causa daquilo... ai... fragilzinha... eu me lembro disso na minha adolescência... (risos)... Eu tinha uma raiva e dizia: são essas idiotas que mantém isso... No filme em que a mulher torcia o tornozelo... o leão quase atacando e a mulher me torce o tornozelo?... me dava uma raiva... eu queria mostrar que a mulher era capaz... e até melhor... Eu não tinha essas coisas de menina boba... Até no esporte... tinha umas meninas tão desajeitadas... e eu jogava bem, eu gostava de competir... e com os meninos então... (risos) eu gostava mais ainda... (risos) Mas quando eu entrei na puberdade a coisa mudou um pouquinho... (risos)

$\mathrm{Na}$ adolescência eu lia aquelas histórias... via aquelas mulheres missionárias na Amazônia... ajudando os índios... eu achava o máximo... (risos) ai, ai, ai... (risos) eu achava assim o supra-sumo do supra-sumo... Eu queria ser uma daquelas mulheres... ali pelos quinze, dezesseis anos

Eu me lembro que sempre fui muito curiosa, gostava muito da natureza... e meu pai dizia:

Ah... quem é curioso, quem gosta da natureza é biólogo ou é geólogo... Mas eu pensava... O que é que eu vou fazer?

O meu pai, sempre foi um homem com um temperamento extremamente calado... Ele não é de fazer grandes comentários... Meu pai é a pessoa que a família inteira vem pedir conselho, a pessoa que todo o mundo considera uma pessoa superior... Bem... ele é um Juiz... e acho que ele assume bem aquele papel de Juiz... Ele é ponderado, sempre vê os dois lados da moeda... não emite crítica... A gente fala sobre uma pessoa... Ele sempre diz: ela deve ter os seus motivos... sempre me passou isso... Meu pai sempre me passou ser uma pessoa justa, uma pessoa bondosa, uma pessoa muito inteligente... nunca emite comentários bobinhos... assim do dia a dia... mas isso também faz falta... Então ao mesmo tempo eu senti um pai ausente... Eu o sentia distante... mas por outro lado, sempre que eu precisei, ele estava lá... mesmo meio no andar de cima... meio como uma perfeição, sabendo o certo e o errado... E essa imagem não é só para 
mim... mas acho que para todo mundo... Na identificação com a figura masculina, a imagem de homem, o estereótipo de homem estaria ligada à figura dele... Mas eu fui buscar o contrário... Porque quando eu analiso o que eu busquei, com o meu marido, que foi meu primeiro namorado... ele é o oposto... ( $\left.2^{\circ}\right)$

Entre a década de sessenta e setenta a questão da repressão estava muito presente e a ideologia da igreja católica dominava o pensamento de todos os educadores. As noções morais tinham o objetivo de preservar os bons costumes. O setor editorial era dominado pelo livros das Edições Paulinas, os únicos recomendados para os jovens. A religião teve influência na repressão da sexualidade e foi utilizada para reforçar os princípios de comportamentos aceitos como corretos para o homem e a mulher.

Na adolescência você começa a se dar conta... começa a questionar mais... e a minha mãe começou a contar muita coisa... das dificuldades dela... Hoje eu acho que por isso na infância ela procurava orientar... Ela comprava para a gente ler e discutir os livros das Irmãs Paulinas... livros sobre sexualidade... a gente lia... a gente questionava... ( $\left.2^{\circ}\right)$

Com dezessete anos foi a paixão... quando conheci meu marido... hoje vejo... Ele é completamente diferente... Ele é tudo aquilo que eu queria no meu pai... mais pé no chão... Eu prefiro que fale... mais humano... que dá palpite... que vê defeito... que pode ver até os meus defeitos... É o oposto.... Aí eu comecei a ver o homem realmente como ele pode ser... como uma mulher... porque eu tinha aquela imagem que a mulher era até superior, eu lembro que na adolescência eu achava que a mulher era superior mesmo... que os homens, realmente... não estavam com nada... Era um ser possuidor de necessidades vis e baixas... não só nesse campo aí... mas quando eu conheci meu namorado na época, hoje meu marido, foi aí que eu vi... meu Deus, que realmente não tinha nada a ver, que aquilo era muito próprio do meu pensamento... Foi aí que eu fiz as pazes com os homens... senão estaria me defendendo dos homens até hoje... ao invés de compartilhar... $\left(2^{\circ}\right)$

Como eu comecei a namorar tarde... estava já no primeiro ano de medicina... e a coisa foi evoluindo como se eu fosse uma menina de doze, treze... Foi natural... não teve nada complicado na sexualidade... porque agora eu queria... era uma coisa boa... era uma coisa normal para mim... Minha mãe relaxou na parte sexual... naquele 'toma cuidado'... E no curso eu já comecei 
o namoro com meu marido... com dezessete anos eu entrei na faculdade e já comecei a namorar... Foi muito bom para mim e para ele... Foi uma descoberta para mim... foi uma experiência maravilhosa... Imagine, a pessoa que você ama, que tem atração... e ir descobrindo aos poucos e junto com a afetividade... tudo aquilo que eu li, a gente tinha a opção de discutir... olha, a gente tem desejo, tem atração... Tudo que a gente estuda e que eu li sobre sexualidade, meus Deus do céu, que bom... para mim foi tudo assim... $\left(2^{\circ}\right)$

$\mathrm{O}$ adolescente necessita de apoio para encontrar o seu caminho, porque uma mudança exige coragem e desestabiliza, cria dúvidas e incertezas, mas é muito mais saudável do que uma atitude de acomodação.

\subsection{A carreira profissional}

A carreira profissional vai se construindo num processo dinâmico junto com o amadurecimento da personalidade. Constitui uma condensação de vivências, experiências, interesses, habilidades e possibilidades, tendo por base as representações reais e ideais do mundo profissional. Entram em jogo os conhecimentos adquiridos e uma ordem de valores.

Na minha idéia, desde os doze anos eu queria fazer medicina. Eu sou a única médica da família... Desde os doze anos eu quero ser médica. Eu não me lembro de antes, mas... Eu me lembro que quando fui estudar o corpo humano na sexta série...meu Deus... eu me fascinei por aquilo... você junta... gostar do corpo humano mais querer ajudar as pessoas? Medicina... $\left(2^{\circ}\right)$

A escola inglesa de psicanálise afirma que a escolha da profissão é uma resposta inconsciente a um chamado interno como exigência do ego para reparar um objeto interno danificado. A satisfação pessoal e profissional presentes nas reflexões são sinais de que a profissão "deu conta" desse chamado interno.

Eu gosto do que faço... Muito mais do que o conhecimento técnico eu preciso da dimensão humana... (risos) eu preciso... Eu preciso dessa troca... No começo eu tinha muita dificuldade de empatia... com o adolescente... porque acho que é uma coisa que a gente vai trabalhando com o tempo... ( $\left.2^{\circ}\right)$

O carreira profissional não é a soma nem o produto de cursos e conhecimentos. As escolhas vão ocorrendo num processo dinâmico que abrange 
toda a vida profissional. A teoria da psicologia da carreira profissional de SUPER (1957) supõe que o sujeito opta entre alternativas a partir de escolhas anteriores e sucessivas, considerando suas características pessoais. As escolhas se fazem em função do autoconceito em sucessivas resignificações mas seguindo sempre um fio condutor. Esse desenvolvimento se dá de forma orientada e por estágios, na medida em que resulta da interação entre a bagagem do sujeito e a solicitação da cultura.

Por que eu faço o que faço hoje?... Essa é uma questão que me levou a refletir muito... Depois eu vi... meus Deus, a vida inteira meu pai ajudou os outros... eu quero fazer mais ou menos o que ele fez... e aonde que eu posso ajudar os outros? É ouvindo os outros, é ajudando a curar as doenças dos outros... sem deixar de ser um forma de poder também... Ser tão poderosa quanto um Juiz... Eu sempre procurei fazer o mais difícil... A profissão veio pela via de ajudar os outros... É... é isso... o interesse em ajudar os outros... ( $\left.2^{\circ}\right)$

A ciência era, e aliás continua sendo, assexuada no período dos anos sessenta a oitenta. Também não se fala em sexo ou sexualidade no cursos de formação da área biológica e de saúde, nem mesmo no curso de medicina. Apenas no final de oitenta surgem algumas iniciativas em alguns cursos. Se a sexualidade não fazia parte dos cursos de formação também não fazia parte da prática profissional. Na medicina os conhecimentos sobre a função sexual resumiam-se à vertente reprodutora ou às doenças e disfunções do aparelho reprodutor. $\mathrm{O}$ sexo era tratado via doença. Sobre a sexualidade na sua dimensão psicológica, em desejo e prazer, no aspecto sócio-cultural de práticas e comportamentos, não se falava nada. A inovação na prática profissional representava um desafio e provocava reações porque desestabilizava o já consagrado.

A medicina era uma profissão basicamente masculina... tanto que eu entrei e disse: eu vou fazer medicina e jamais farei pediatria nem ginecologia, porque essa é uma especialidade que as mulheres querem... eu vou mostrar que a mulher... (risos) feminista eu era... como é que pode... (risos) mas teve essa fase... E o que eu faço hoje?... Sou pediatra... justo eu... Mas veja o que aconteceu... na prática do dia a dia começam a surgir as dúvidas, as perguntas sobre sexualidade... eu não sabia o que ia responder.. Incomoda... Aí você começa a se informar mais... O curso de medicina é totalmente assexuado... Na faculdade não se toca em assunto de sexo... não se fala nesse assunto... Eu sinto que eu fui tão feliz em relação a descoberta da sexualidade... mas comecei a ver que tem pessoas que são tão infelizes... 
E o pediatra é muito de orientar... Eu sempre gostei muito de conversar e de orientar... e de repente você começa a estudar e a ver que as pessoas precisam daquilo. No consultório o pai e a mãe criticando o adolescente, rotulando... $O$ clínico não quer saber da criança, meu Deus do céu, como é que eu vou responder? A partir do momento que comecei a ler qualquer coisa sobre o adolescente me apaixonei... por querer ajudar também... $\mathrm{E}$ depois você vê que tem uma demanda... que ninguém faz aquilo... meu Deus, ninguém faz aquilo... ninguém gosta do adolescente... a gente se apaixona por esse potencial de mudança, por tudo que representa a própria adolescência... À medida que eu fui lendo sobre adolescência, o que me fez gostar muito, foi porque na minha casa meus pais sempre ajudaram na minha autonomia... você decide... ao mesmo tempo em que eles me protegiam na sexualidade, por exemplo, diziam: você vai sofrer a conseqüência... a vida é tua.... a responsabilidade é tua... E eu sentia na família do meu marido o contrário... que se metiam, se intrometiam nas decisões... e bloqueavam esse crescimento.. Graças a Deus meu marido tem uma personalidade fortíssima... mas isso atrapalha... E à medida que eu lia isso sobre os adolescente, do direito da autonomia, do crescimento, que a gente aprende com erro e com acerto... eu me lembro que quando eu tinha dezessete, dezoito anos, ainda adolescente...eu usava isso para o lado meu também... Depois de casada eu lia aquilo e dizia assim: Coitados dos adolescentes... Eu pensava no passado... ( $\left.2^{\circ}\right)$

\subsection{Fases da carreira profissional}

Na perspectiva clássica da análise da carreira profissional, uma série de atividades de experimentação e diversificação são características do período exploratório antes da estabilização. No início da carreira, diante de um leque de opções, há uma fase "exploração" e de "diversificação". Uma auto-avaliação constante do grau de satisfação pessoal levam a perceber inconsistências e limitações. É a fase em que o profissional está mais motivado e busca uma especialização sentindo a necessidade de se comprometer com algum projeto que contenha a sua marca pessoal.

Como pediatra eu atendo crianças até doze anos, como todo mundo atende. Só que nessa população de doze anos você começa a ver um sofrimento naquele jovem. E vê que ninguém entende nada, muito menos eu... não entendia de nada... só sabia que aquele jovem estava ali, coitado... me fazendo um monte de pergunta... $\mathrm{O}$ pai e a mãe criticando, rotulando... $\mathrm{O}$ 
clínico não quer saber da criança, e meu Deus do céu, como é que eu vou responder?

Por que será que eu sempre quis ajudar os outros? A vida profissional vai seguindo certos ciclos... Eu me questionei de um monte de coisa na minha vida... A minha profissão tem a ver com a minha história de vida... tem tudo a ver... não foi uma decisão racional... Quando comecei os atendimentos a adolescentes comecei a me pôr em questão... a fazer questões... e a assumir uma postura não somente de pediatra, mas de educadora na sexualidade... Acho que amadureci muitíssimo nesse período. É um processo... e é muito bom... Eu até achava que estava na crise de adolescente... nunca atravessei grandes crises, aquela crise existencial que tem o adolescente eu não tive... tive depois... (risos)... Na pediatria eu gosto muito mais da parte de prevenção ambulatorial... Veja a minha opção... eu faço ambulatório, não trabalho em hospital... Por que? Porque eu gosto muito mais da parte de prevenção... de orientação de puericultura, faz a sopinha assim... é educação. Dentro da pediatria eu tinha um leque de opções... Podia ser neonatologista, trabalhar só em UTI, trabalhar só em hospital, tem colega que odeia consultório... Eu ao contrário... eu faço só consultório... Porque é conversar... é bater papo... é orientar... Gosto muito mais disso do que uma emergência... Eu odeio uma UTI... Eu odeio uma cirurgia... odeio... odeio

É muito técnico... (reflexão)

E o trabalho como educadora sexual surgiu assim... fui mudando no sentido de deixar um trabalho curativo e fui passando para um papel de educadora sexual... Eu tenho dez anos de profissão... e gosto de trabalhar com adolescência... mas eu não tenho pressa... Eu gosto de pisar muito firme onde estou pisando... Primeiro eu fiz um ano de acompanhamento em um ambulatório de adolescentes, para depois eu começar a trabalhar com adolescente... indo bem devagarinho... Hoje já trabalho dois anos com adolescentes diariamente... Agora estou acabando o meu pós graduação em adolescência. É uma construção... é assim que eu vejo. Eu não gosto de colocar um tijolo aqui, o cimento ainda não está bom, eu não sou assim, é uma questão de personalidade... ( $\left.2^{\circ}\right)$

No desenvolvimento da carreira profissional surgem desafios em vários momentos. Alguns acontecimentos da vida levam a pessoa a "pôrse em questão". São várias fases arquetípicas da vida, durante a qual a pessoa pára para uma reflexão existencial e vê-se diante de caminhos e 
bifurcações. A dimensão da temporalidade torna possível a unidade do tempo vivido no passado e no presente e a transcendência para possibilidades futuras.

Sofria demais em relação a problemática do adolescente... Não conseguia separar até onde podia ajudar e até onde a pessoa tem que se ajudar... Hoje eu consigo separar... a gente vai amadurecendo... Eu até busquei uma psicoterapia e vou continuar este ano...

Quanto mais você lida com o jovem e você vê aquele processo de auto conhecimento... a gente revive um monte de coisas. Eu tenho vivido isso, desde que trabalho com adolescente, dos 28 anos para cá... fazem cinco anos que eu estou trabalhando com adolescente... eu tenho sentido... não sei se coincide com a fase da vida... se não estivesse trabalhando com adolescente...não sei... ( $2^{\circ}$ )

Examinam o que já fizeram e deu certo e encaram a perspectiva de continuar no mesmo percurso, ou mudar a trajetória. A criança que fica "grande" e que vive no adulto, insiste em estar aí, e é a partir deste novo lugar que faz suas demandas e conta insistentemente a sua história de vida. As experiências marcantes vividas na infância representam marcos que vão demandar um trabalho de re-significação. Após essa fase da carreira desembocam num estádio do comprometimento definitivo ou de estabilização. Na vida profissional tem o significado de emancipação e independência. O profissional afirma perante os outros o seu modo de funcionamento.

Eu estou começando a me estabilizar agora... estou no início ainda... Aí que a gente vai ver... Não sei se o resultado vai ser bom, se vai ser legal ou não vai... Falo sempre, não diga... faça... Só posso saber depois de vivenciar... eu estou na fase de investir em mim mesmo e na sua profissão... Agora vou vivenciar isso... ( $\left(2^{\circ}\right)$

\section{CONCLUSÕES}

A história de vida vai conduzindo o fluir da existência, confirmando o pensamento de Heidegger de que a existência precede a essência. A investigação da experiência profissional é importante porque o homem é um potencial contador de histórias e mostra como cada um sente o mundo. É o que Giddens denomina de "confisco da experiência" (In: NÓVOA, 1995, 
p. 17), afirmando que o importante não é o que cada um fez mas o que conseguiu fazer com o que os outros fizeram com ele.

A interpretação do discurso é uma tarefa fascinante porque a história de vida fala por si só e articula-se com o referencial teórico, como duas faces da mesma moeda, além de retratar o imaginário social da época.

O sujeito se reconhece na história que conta de si próprio, demonstrando que a formação do educador sexual passa necessariamente pela sua pessoa, imbricada com o seu tempo vivido, e no "como" resolveu as suas próprias dificuldades em relação à sexualidade. A história de vida articulase com o referencial teórico como duas faces da mesma moeda.

É fundamental a representação da sexualidade na sua história de vida.

A imposição da culpa exercida pela religião está presente nos pensamentos e comportamentos infantis. A curiosidade e a repressão caminham juntas na busca de respostas para os enigmas da vida. $\mathrm{O}$ que foi buscado pelo sujeito como brincadeiras que traziam satisfação carregavam junto o medo e geravam culpa. Na tentativa de controlar o comportamento a ameaça está sempre presente.

A família, explicitamente a mãe foi quem passou as primeiras mensagens sobre sexualidade. Essas mensagens foram registradas e incorporadas nos seus comportamentos. Por isso a educação sexual que a escola possa vir a oferecer acaba sendo um processo tardio, pois quando a criança chega lá, e hoje ela chega cada vez mais cedo, já traz uma coleção de crenças e preconceitos. O que a escola pode fazer é discutir sobre tudo isso, a partir de uma informação científica e contextualizada.

A análise do discurso demonstrou a evolução do Édipo infantil, segundo a teoria psicanalítica, com relatos de forte componente afetivo, onde a importância da figura paterna está presente na significação da sexualidade e dos papéis sócio-sexuais.

O curso de medicina foi classificado como assexuado, situação que na atualidade permanece quase a mesma, com algumas exceções.

Uma auto-avaliação levou o sujeito a buscar alternativas de formação complementar para continuar a caminhada. Ao mesmo tempo que denunciou a falta, mobilizou-se para encontrar cursos de aperfeiçoamento que complementassem o conhecimento e dessem conta das questões postas na prática profissional.

Para auto conhecimento e equilíbrio emocional recorreu a uma análise pessoal para tentar resolver conflitos entre o "eu pessoal" e o "eu profissional". Nem todos, entretanto, têm essa atitude consciente. Preocupam-me aqueles que, apenas com os conteúdos mínimos dos currículos da formação acadêmica se põem em ação com práticas e técnicas questionáveis e improvisadas. Colaboram para aumentar ainda mais a distância entre o saber e a realidade.

A história de vida deixou claro que um sólido conhecimento científico é importante, mas insuficiente. A dimensão emocional é fundamental 
quando se estabelece uma relação de ajuda. O laço afetivo é imprescindível numa atitude compromissada e responsável. Mais importante que o domínio do conhecimento é o que o educador faz com esse conhecimento. $\mathrm{O}$ momento em que a pessoa se dá conta das dificuldades e "se põe em questão" é decisivo. A resposta obtida leva a outra questão: $O$ que faço com esse conhecimento? O desejo de melhorar o seu desempenho impulsionou para um estado de educação permanente. Essa fase da carreira profissional coincide com uma avaliação da trajetória percorrida e a conscientização dos fatos significativos e as figuras que atuaram como modelos identificatórios. A história de vida parece confirmar o pressuposto da teoria psicanalítica de que a escolha profissional é uma resposta inconsciente do Ego que tenta reparar um objeto interno danificado.

$\mathrm{Na}$ relação de ajuda que o educador sexual estabeleceu considerou mais importante a dimensão afetiva do que o conhecimento, a qualidade do vínculo do que a atuação técnica. Valoriza a dimensão humana e a empatia.

A apropriação do sentido e da riqueza emergente na história de vida confere um estatuto a esse saber.

\section{PROPOSIÇÕES}

Proponho que valorizemos paradigmas que promovam a formação de profissionais dispostos a participar na implementação de propostas educativas, uma necessidade premente no Brasil atual. O momento exige que o educador possa "habitar aquilo que constrói" e possua a coragem para dar o "pulo necessário e arriscar". Refletindo sobre a questão: Quem educa o educador? Considero que esse papel está afeto à universidade. Numa sociedade em crise, ainda é o local mais apropriado para a informação e a formação do educador. O cerne da formação do educador sexual é a visão que ele tem sobre a sexualidade.

HEIDEGGER (1973) em "Qu'appelle-t-on penser" afirmou:

Ensinar é ainda mais difícil do que aprender. Mas raramente se pensa nisso. Por que ensinar é mais difícil que aprender? Não porque o mestre deva possuir um maior acervo de conhecimentos e tê-los sempre à disposição. Ensinar é mais difícil do que aprender, porque ensinar quer dizer "deixar aprender". Aquele que verdadeiramente ensina não faz aprender outra coisa que não seja o aprender. O mestre deve ser mais ensinável que os alunos e muito menos seguro de seu ofício que os alunos do seu. Ele deve aprender a "deixar aprender".

É necessário envolver todo o "Ser" na reconstrução da realidade. 


\section{REFERÊNCIAS BIBLIOGRÁFICAS}

ALBERTI, V. História oral: a experiência do CPDOC. Rio de Janeiro: Fundação Getúlio Vargas, 1990.

AMATUZZI, M. M. O resgate da fala autêntica - Filosofia da psicoterapia e da educação. Campinas, SP: Papirus, 1989.

BARDIN, L. Análise de conteúdo. São Paulo: Martins fontes, 1977.

BOHOSLOVSKY, R. Orientación vocacional: la estrategia clínica. Buenos Aires: Nueva Visión, 1976.

CORREIA, G. B. Educação e Vida em Sexualidade: uma visão interface. Curitiba, 1991. Projeto de Educação Sexual (Curso de Pós-Graduação em Sexualidade Humana) - Centro de Pesquisa e Pós-Graduação, Faculdade de Ciências e Letras Tuiuti.

. Sexualidade e educação. Revista da Linha de Pesquisa Currículo e Conhecimento. Programa de Pós-Graduação em Educação - UFPR, Curitiba, v. 1, n. 1, p. 28-38, jan./jun. 1997.

DELAMONT, S. Os papéis sexuais e a escola. Lisboa: Horizonte, 1985.

FAGUNDES, T. C. P. C. Educação sexual - construindo uma nova realidade. Salvador: Instituto de Biologia da Universidade Federal da Bahia, 1995.

FREUD, S. A educação sexual da criança. Rio de Janeiro: Delta, 1945. Teorias sexuais infantis. Rio de Janeiro: Delta, 1945.

GIL, A. C. Métodos e técnicas de pesquisa social. São Paulo: Atlas, 1987. 206 p.

HEIDEGGER, M. Qu'appelle-t-on penser. Paris: Gallimard: 1973, p. 89.

MEDINA, C. de A. Entrevista: o diálogo possível. São Paulo: Ática, 1986. 96 p. (Princípios, 105).

MONEY, J. Conferência de Abertura. In: XI CONGRESSO MUNDIAL DE SEXOLOGIA (1994: Rio de Janeiro). Anais... Rio de Janeiro, 1994. p. 1-5.

NÓVOA, A. Vidas de professores. 2. ed., Porto: Porto Editora, 1995.

SILVA, A. C. Resumo de aulas expositivas. Curso de Pós-Graduação em Sexualidade Humana. Curitiba, 1990-91.

SUPER, D. The psychology of careers. New York: Harper \& Row, 1957.

VITIELLO, N. Redação e apresentação de comunicações científicas. BYK, 1998. $155 \mathrm{p}$. 